\title{
Cetuximab Induced Aseptic Meningitis: A Rare Side Effect
}

Supreet Kaur, Hazera Khatun, Abhishek Kumar*, Michael Ellis, Dhruv Mehta and Gunwant Guron

Department of Haematology and Oncology, St Joseph Regional Medical Center, New Jersey, USA

\begin{abstract}
A 65-year-old African American female was diagnosed with laryngeal cancer $\left(T_{1} N_{2} M_{0}\right)$ in August 2015 . She received platinum-based chemotherapy initially. After an initial remission patient had a systemic recurrence which was treated with Cetuximab. The patient presented to ER six hours after receiving the first dose of cetuximab with high grade fever and signs of meningeal irritation. CSF analysis showed neutrophil predominant pleocytosis with negative gram stain and culture. It was concluded that the patient had cetuximab induced aseptic meningitis. The patient was re-challenged with lower dose of cetuximab which was tolerated well. Cetuximab induced aseptic meningitis is a rare side effect reported in handful of cases.
\end{abstract}

Keywords: Cetuximab; Aseptic meningitis; Laryngeal cancer; Meningeal irritation; Chemotherapy

\section{Introduction}

Cetuximab is a chimeric IgG1 monoclonal antibody against EGFR and is used for EGFR expressing metastatic colorectal cancer and squamous cell cancer of head and neck [1]. The common side effects of cetuximab include infusion like reaction, cytokine release syndrome, rash, dry skin and nail changes, nausea, malaise, fatigue and transaminitis [2]. Aseptic meningitis is a rare side effect and there are only few case reports describing this effect. We report a case of aseptic meningitis after the first dose cetuximab in a patient with metastatic head and neck cancer.

\section{Case Presentation}

Our patient is a 65-year-old African American female with past medical history of COPD, Hepatitis C s/p treatment, ex-smoker with 45 pack years who was diagnosed with laryngeal cancer $\left(\mathrm{T}_{1} \mathrm{~N}_{2} \mathrm{M}_{0}\right)$ in August 2015. She initially received induction chemotherapy with docetaxel, 5 -flurouracil and cisplatin for three cycles followed by concurrent chemo-radiation therapy with carboplatin with complete response. Sixteen months later, she had her first recurrence as a solitary lung nodule which was treated with wedge resection of lung and adjuvant radiotherapy, following which she had second recurrence six months later in pre-carinal and mediastinal nodes. In view of poor tolerance of previous chemotherapy, decision was made to start her on single agent Cetuximab.

Earlier on the day of admission, patient had received her first dose of cetuximab $\left(700 \mathrm{mg}\right.$ as $\left.400 \mathrm{mg} / \mathrm{m}^{2}\right)$ after pre medication with $\mathrm{H} 1$ antagonist, diphenhydramine $25 \mathrm{mg}$ IV. She returned to ER 6 hours after treatment at cancer center with a fever of $103 \mathrm{~F}$ and chills. She exhibited photophobia, neck stiffness and headache. Vital signs on admission were: Temperature $39.1^{\circ} \mathrm{C}$, BP $170 / 91 \mathrm{mmHg}$, HR $89 / \mathrm{min}$, RR 14/min with oxygen saturation of $97 \%$ on room air. Her physical exam was unremarkable except for neck rigidity. Rest of the neurological exam was benign.

Laboratory data on admission showed WBC 3.00 per microliter, Hb 11.5 g/dL, Hct 32.3, Platelets 100 per microliter, absolute neutrophil count of 2800 , C-reactive protein was normal at $1 \mathrm{mg} / \mathrm{dL}$. CT scan of the head without contrast was performed which showed no acute intracranial findings. The patient was started on empiric broad spectrum antibiotics after lumbar puncture was performed. CSF analysis showed normal glucose $(48 \mathrm{mg} / \mathrm{dL})$, elevated protein $(111.7 \mathrm{mg} / \mathrm{dL}), \mathrm{WBC}$ of 321/ul with neutophilic pleocytosis. PMN were 91\% and 3\% were lymphocytes.

CSF Gram stain, culture, PCR for viruses and cryptococcal antigen were negative. Blood cultures remained negative. Antibiotics were stopped on day 3 of admission after all workup came back negative and patient was afebrile. At the same time clinically the patient improved with resolution of headache and photophobia. It was concluded that the patient had aseptic meningitis likely due to cetuximab. After two weeks, patient successfully received re-challenge at a dose of $250 \mathrm{mg} / \mathrm{m}^{2} ; 435$ $\mathrm{mg}$ with $12 \mathrm{mg}$ of dexamethasone and $25 \mathrm{mg}$ of diphenhydramine as premedication. Until this report she has completed 3 more weekly doses without any recurrence of meningeal irritation.

\section{Discussion}

Aseptic meningitis refers to clinical and laboratory evidence of meningeal inflammation with negative bacterial culture. Enteroviruses are the most common causes. Other causes include fungi, medications for example, infliximab, azathioprine, NSAIDs. It has also been associated with malignancies and autoimmune disease like sarcoidosis and SLE [3]. Aseptic meningitis has been reported as a rare side effect of cetuximab therapy. The first occurrence of drug-induced aseptic meningitis related to cetuximab was reported in 2000 by Baselga et al. in a phase I clinical trial [4]. Most of the literature is limited to case reports which describes this side effect within the first 24 hours after the first dose (Table 1) [1]. The diagnosis is largely one of exclusion after ruling out bacterial and viral etiologies. It is treated with empiric antibiotics until a microbiologic diagnosis is established as in our case.

The mechanism is largely unknown. Aseptic meningitis has been reported to be associated with other immunoglobulin treatment including IVIG $[1,4,5]$. It has been postulated that IgG can cross the blood brain barrier and induce inflammatory reaction in the meninges and cetuximab could potentially share the same mechanism [1,5]. Other possible mechanisms include hypersensitivity reaction which could

*Corresponding author: Abhishek Kumar, Department of Haematology and Oncology, St Joseph Regional Medical Center, 703 main street Paterson, New Jersey, USA, Tel: + (973) 955 3692; E-mail: mresearch.ak@gmail.com

Received June 20, 2018; Accepted August 09, 2018; Published August 13, 2018

Citation: Kaur S, Khatun H, Kumar A, Ellis M, Mehta D, et al. (2018) Cetuximab Induced Aseptic Meningitis: A Rare Side Effect. J Cancer Sci Ther 10: 211-213. doi: 10.4172/1948-5956.1000546

Copyright: (c) 2018 Kaur S, et al. This is an open-access article distributed unde the terms of the Creative Commons Attribution License, which permits unrestricted use, distribution, and reproduction in any medium, provided the original author and source are credited. 
Citation: Kaur S, Khatun H, Kumar A, Ellis M, Mehta D, Guron G (2018) Cetuximab Induced Aseptic Meningitis: A Rare Side Effect. J Cancer Sci Ther 10: 211-213. doi: 10.4172/1948-5956.1000546

\begin{tabular}{|c|c|c|c|c|c|c|c|c|}
\hline Article & $\begin{array}{c}\text { Age } \\
\text { of } \\
\text { patient }\end{array}$ & Diagnosis & $\begin{array}{c}\text { Dose } \\
\left(\mathbf{m g} / \mathrm{mt}^{2)}\right)\end{array}$ & Symptoms & $\begin{array}{l}\text { Time of } \\
\text { onset }\end{array}$ & CSF findings & $\begin{array}{c}\text { Treatment and time } \\
\text { to recovery }\end{array}$ & $\begin{array}{l}\text { Re-challenge/dose/ } \\
\text { premedication }\end{array}$ \\
\hline \multirow{5}{*}{ [1] } & \multirow{5}{*}{66 y } & \multirow{5}{*}{$\begin{array}{c}\text { Locally advanced } \\
\text { laryngeal SCC }\end{array}$} & \multirow{5}{*}{400} & \multirow{5}{*}{$\begin{array}{c}\text { Headache, neck stiff } \\
\text { ness photophobia } \\
\text { nausea vomiting }\end{array}$} & \multirow{5}{*}{$\begin{array}{l}\text { Few } \\
\text { Hours }\end{array}$} & WBC 4100/ul. & \multirow{5}{*}{$\begin{array}{l}\text { Empiric antibiotic/ } \\
\text { Recovery within } \\
\text { several days. }\end{array}$} & \multirow{5}{*}{$\begin{array}{c}\text { Negative re-challenge } \\
\text { after } 28 \text { days, } 250 \\
\mathrm{mg} / \mathrm{mt}^{2} \text { with SMD and } \\
\text { DPH. }\end{array}$} \\
\hline & & & & & & PMN pleocytosis $(90 \%)$ & & \\
\hline & & & & & & High protein $(1.5 \mathrm{~g} / \mathrm{L})$ & & \\
\hline & & & & & & Normal Glucose & & \\
\hline & & & & & & $\begin{array}{l}\text { Negative bacterial and viral } \\
\text { culture }\end{array}$ & & \\
\hline \multirow{4}{*}{ [6] } & \multirow{4}{*}{$58 y$} & \multirow{4}{*}{ Tonsillar SCC } & \multirow{4}{*}{400} & \multirow{4}{*}{$\begin{array}{l}\text { Frontal headache } \\
\text { Fever }\end{array}$} & \multirow{4}{*}{1 hour } & WBC $473 /$ ul & \multirow{4}{*}{$\begin{array}{c}\text { Empiric antibiotic/ } \\
\text { Recovery within } 4 \\
\text { days }\end{array}$} & \multirow{4}{*}{$\begin{array}{l}\text { Negative re-challenge } \\
\text { at dose } 250 \mathrm{mg} / \mathrm{mt}^{2}\end{array}$} \\
\hline & & & & & & PMN pleocytosis $(80 \%)$ & & \\
\hline & & & & & & High protein $(1.28 \mathrm{~g} / \mathrm{L}$ & & \\
\hline & & & & & & Normal Glucose & & \\
\hline \multirow{4}{*}{ [7] } & \multirow{4}{*}{$78 y$} & \multirow{4}{*}{ NSCLC } & \multirow{4}{*}{400} & \multirow{4}{*}{$\begin{array}{l}\text { Severe headache, } \\
\text { nausea, vomiting }\end{array}$} & \multirow{4}{*}{$\begin{array}{l}\text { Few } \\
\text { Hours }\end{array}$} & WBC 528/ul. & \multirow{4}{*}{$\begin{array}{l}\text { Empiric antibiotic/ } \\
\text { Recovery time not } \\
\text { reported }\end{array}$} & \multirow{4}{*}{ Not reported } \\
\hline & & & & & & PMN pleocytosis $(87 \%)$ & & \\
\hline & & & & & & High protein & & \\
\hline & & & & & & Normal glucose & & \\
\hline [7] & $59 y$ & $\begin{array}{l}\text { Metastatic } \\
\text { NSCLC }\end{array}$ & 400 & $\begin{array}{c}\text { Acute } \\
\text { encephalopathy }\end{array}$ & Few & $\begin{array}{c}\text { Elevated protein }(1.16 \mathrm{~g} / \mathrm{L}) . \\
\text { Cell count and differential not } \\
\text { reported. }\end{array}$ & $\begin{array}{l}\text { Empiric antibiotic/ } \\
\text { Several days }\end{array}$ & Not reported \\
\hline & & & & & & Negative culture & & \\
\hline & & & & & & WBC 1025/ul. & & recurrence of \\
\hline & & & & & & PMN pleocytosis $(92 \%)$ & & symptoms after \\
\hline & & Squamous cell & 400 & Frontal headache, & Few & High protein (1.65 g/L) & Empiric antibiotic/ & $\begin{array}{c}\text { rechallenge at } 250 \\
\mathrm{mg} / \mathrm{mt}^{2}\end{array}$ \\
\hline [8] & $54 \mathrm{Y}$ & maxillary cancer & & $\begin{array}{l}\text { neck discomfort, } \\
\text { Fever } 39.9^{\circ} \mathrm{C} \text { fever }\end{array}$ & Hours & Normal glucose & $\begin{array}{l}\text { Recovery time not } \\
\text { reported }\end{array}$ & $3^{\text {rd }}$ and subsequent \\
\hline & & & & & & Negative culture and HSV PCR & & unremarkable. \\
\hline & & & & & & WBC 2300/ul. & & \\
\hline & & & & Frontal headache, & & PMN pleocytosis $(98 \%)$ & Empiric antibiotic, & Successful at 1 week, \\
\hline [9] & $45 \mathrm{y}$ & $\begin{array}{l}\text { Recurrent } \\
\text { RcC }\end{array}$ & 400 & Fever $38.3^{\circ} \mathrm{C}$ & Few & High protein (1.04 g/L) & acyclovir/Recovery & $250 \mathrm{mg} / \mathrm{mt}^{2} / \mathrm{DPH}$ \\
\hline & & & & & & Normal glucose & & \\
\hline & & & & & & Negative culture & & \\
\hline & & & & & & WBC 2267/ul & & \\
\hline & & & 100 & Frontal headache, & & PMN pleocytosis $(90 \%)$ & Empiric antibiotic, & Successful at 2 \\
\hline [9] & $42 y$ & 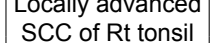 & 400 & Fever $39.4^{\circ} \mathrm{C}$ & Hours & High protein $(1.46 \mathrm{~g} / \mathrm{L})$ & acyclovir. DEX/ & weeks $/ 250 \mathrm{mg} / \mathrm{mt}^{2} /$ \\
\hline & & & & Photophobia & & Normal glucose & Recovery at 12 days. & DPH and DEX \\
\hline & & & & & & Negative culture & & \\
\hline & & & & & & WBC 1413/ul & & \\
\hline & & & & & 9 & PMN pleocytosis $(92 \%)$ & Empiric antibiotic & Patient refused re- \\
\hline [10] & $67 y$ & oropharyngeal & 400 & $\begin{array}{l}39.2 \mathrm{C} \\
\text { Headache }\end{array}$ & Hours & High protein $(1.79 \mathrm{~g} / \mathrm{L})$ & and DEX/Recovery & challenge. \\
\hline & & SCC & & & & Normal Glucose & within 14 days & \\
\hline & & & & & & Negative culture and serology. & & \\
\hline & & & & & & WBC $321 / \mathrm{ul}$ & & \\
\hline & & & & & & PMN pleocytosis $(91 \%)$ & & \\
\hline Current & $65 \mathrm{v}$ & Metastatic & 400 & Fever $39.4^{\circ} \mathrm{C}$ & 6 & High protein $(1.1 \mathrm{~g} / \mathrm{L})$ & Empiric antibiotic/ & Negative re-challenge \\
\hline case & $00 \mathrm{y}$ & laryngeal cancer & 400 & Photophobia & hours & Normal Glucose & $\begin{array}{l}\text { days. } \\
\text { decove }\end{array}$ & $\mathrm{mt}^{2}$, DEX and DPH. \\
\hline & & & & & & Negative culture & & \\
\hline & & & & & & HSV PCR negative & & \\
\hline
\end{tabular}

Table 1: Review of the case reports.

explain the response to steroid treatment and the use of higher initial loading dose. Chung et al postulated possible IgE mediated reaction related to cetuximab infusion [6-10]. The identified antigen was an oligosaccharide on the fab portion of cetuximab molecule. People who were previously sensitized with either food, tick bites or some parasites had IgE against cetuximab.

Recovery is expected within 1-2 weeks after withdrawal of drug [11]. In our patient, it took three days to recover. Re-challenge with cetuximab even at a reduced dose has been reported to have resulted in recurrence [9] though of the 8 previously reported cases, 2 studies did not report rechallenge, one patient refused rechallenge and in 4 out of five cases rechallenge was successful. Premedication with steroids and restarting at lower dose are reported to be useful which has been seen in our patient $[1,10]$. Though in our patient, we were able to give cetuximab at recommended maintenance dose of $250 \mathrm{mg} / \mathrm{m}^{2}$.

Cetuximab is used for both colorectal and head \& neck SCC. Interestingly, majority of the published case reports of aseptic meningitis were with head and neck cancers. The first 2 cases reported 
were, however, in NSCLC [8]. Grandvuillemin et al studied 602 adverse drug reaction related to cetuximab and found that patients with head and neck cancer were more likely to have infusion reactions and drug related deaths [12] It is unclear whether this side effect is more prevalent in head neck malignancies due to limited number of cases or more frequent reporting by health care professionals because of increased awareness.

\section{Conclusion}

Aseptic meningitis is a rare complication of cetuximab which should be recognized in clinical practice. It would be clinically relevant to evaluate the observed higher incidence of aseptic meningitis in head neck cancer compared to NSCLC and colorectal cancer.

\section{References}

1. Maritaz C, Metz C, Baba-Hamed N, Jardin-Szucs M, Deplanque G (2016) Cetuximab-induced aseptic meningitis: case report and review of a rare adverse event. BMC Cancer 16: 384.

2. Summary of Product Characteristics (2014) [https://ec.europa.eu/health/ documents/community-register/2014/20141205130402/anx_130402_en.pdf]. Accessied on 8th Aug 2018.

3. Shah R, Shah M, Bansal N, Manocha D (2014) Infliximab-induced aseptic meningitis. Am J Emerg Med 32: 1560.
4. Baselga J, Pfister D, Cooper MR, Cohen R, Burtness B, et al. (2000) Phase I studies of anti-epidermal growth factor receptor chimeric antibody C225 alone and in combination with cisplatin. J Clin Oncol 18: 904-914.

5. Sekul EA, Cupler EJ, Dalakas MC (1994) Aseptic meningitis associated with high-dose intravenous immunoglobulin therapy: frequency and risk factors. Ann Intern Med 121: 259-262.

6. Chung $\mathrm{CH}$, Mirakhur B, Chan E, Le QT, Berlin J, et al. (2008) Cetuximabinduced anaphylaxis and $\operatorname{lgE}$ specific for galactose-alpha-1,3-galactose. $\mathrm{N}$ Engl J Med 358: 1109-1117.

7. Prasanna D, Elrafei T, Shum E, Strakhan M (2015) More than a headache: a case of cetuximab-induced aseptic meningitis. BMJ Case Rep 12: 2015.

8. Nagovskiy N, Agarwal M, Allerton J (2010) Cetuximab-induced aseptic meningitis. J Thorac Oncol 5: 751.

9. Emani MK, Zaiden RA (2013) Aseptic meningitis : A rare side effect of cetuximab therapy. J Oncol Pharm Pract 19: 178-180.

10. Feinstein TM, Gibson MK, Argiris A (2009) Cetuximab-induced aseptic meningitis. Ann Oncol 20: 1609-1610.

11. Ulrich A, Weiler S, Weller M, Rordorf T, Tarnutzer AA (2015) Cetuximab induced aseptic meningitis. J Clin Neurosci 22: 1061-1063.

12. Grandvuillemin A, Disson-Dautriche A, Miremont-Salamé G, Fourrier-Reglat A, Sgro C, et al. (2013) Cetuximab infusion reactions: French pharmacovigilance database analysis. J Oncol Pharm Pract 19: 130-137. 